\title{
Analisa kajian literatur Green Building berdasarkan sudut pandang perkembangan ekonomi
}

\author{
Bhenu Artha $^{a, 1}$, Nurina V.Ayuningtyas ${ }^{b^{*}}$, Desy A.K. Murti ${ }^{\text {b }}$, Cahya P. Asri ${ }^{a}$ \\ a Program Studi Kewirausahaan, Fakultas Ekonomi. Universitas Widya Mataram Yogyakarta \\ b Program Studi Arsitektur, Fakultas Sains dan Teknologi, Universitas Widya Mataram Yogyakarta \\ 1 email penulis pertama : bhenoz27@gmail.com \\ * corresponding author : nurinavidya.uwm@gmail.com
}

\begin{tabular}{ll}
\hline Informasi artikel & ABSTRAK \\
\hline Sejarah artikel: & $\begin{array}{l}\text { Industri konstruksi memiliki dampak berbahaya terhadap lingkungan, } \\
\text { Diterima }\end{array}$ ekonomi, dan masyarakat. Sehingga perlu diterapkan pasokan tenaga \\
Revisi & berkelanjutan dimana hal ini dapat diterapkan pada bangunan dengan \\
Dipublikasikan & konsep green building. Wujud perhatian masyarakat di Indonesia terkait \\
\hline Kata kunci: & green building saat ini mulai meningkat dan penerapan green building di \\
Arsitektur Hijau & Indonesia dirasa perlu dilaksanakan. Hal ini dapat dimulai dengan \\
Bangunan Hijau & membuat peraturan yang mendorong aplikasi green building, terutama \\
Ekonomi & untuk perkantoran, sekolah, universitas, yang dapat dimulai dari kantor- \\
Kajian Literatur & kantor pemerintah, seperti halnya yang telah dilakukan dengan adanya \\
& peraturan tentang kendaraan listrik atau bebas emisi. \\
\hline & ABSTRACT \\
\cline { 2 - 4 } & The construction industry has harmful impacts on the environment, \\
Key word: & economy and society. So it is necessary to apply a sustainable power \\
Green Architecture & supply this can be applied to buildings with a green building concept. The \\
Green Building & form of public attention in Indonesia regarding green building is currently \\
Econimic & starting to increase and the implementation of green building in Indonesia \\
Literature Review & is deemed necessary. This can be started by making regulations that \\
& encourage green building applications, especially for offices, schools, \\
& universities, which can be started from government offices, as has been \\
done with regulations on electric or emission-free vehicles.
\end{tabular}

Copyright () 2018 Universitas Widya Mataram Yogyakarta. All Right Reserved

\section{Pendahuluan}

Satu hal ini telah diketahui secara luas oleh masyarakat adalah industri konstruksi memiliki dampak berbahaya terhadap lingkungan, ekonomi, dan masyarakat (Chan dkk, 2017). Industri konstruksi mengonsumsi hingga 40\% dari total energi dan menyumbang hingga 30\% dari total emisi gas rumah kaca tahunan di tingkat global (United Nations Environment Programme (UNEP), 2011). Berkaitan dengan hal tersebut, maka dipandang perlu adanya kerjasama antara kelompk bisnis dengan kelompok lingkungan hidup. Aliansi ini sering disebut green alliances.

Green alliances, kerjasama antara bisnis dengan kelompok lingkungan hidup, merupakan strategi yang efektif untuk mengintegrasikan tanggung jawab perusahaan yang berkaitan dengan lingkungan dan tujuan pasar, dimana green alliances ini menggambarkan beberapa cara perusahaan dapat memperoleh berbagai keuntungan (Kartman dan Stafford, 1997). Energi terbarukan, seperti solar dan energi angin, telah menarik banyak perhatian penelitian karena meningkatnya polusi udara dan penurunan cadangan bahan bakar fosil, namun demikian, kekuatan pasokan matahari dan angin tidak dapat diandalkan karena tergantung pada kondisi cuaca alam semesta. Oleh karena itu, sistem daya hibrida, yang biasanya terdiri dari beberapa sumber energi dan penyimpanan energi, biasanya diterapkan untuk memasok tenaga berkelanjutan (Chen dan Wang, 2017), dimana hal ini dapat diterapkan pada bangunan dengan konsep green building.

Green building juga diketahui sebagai bangunan yang sustainable atau high performance (Guan dkk, 2020). World Commission on Environment and Development (WCED) (1987) menyatakan bahwa sustainable development merupakan pengembangan yang memenuhi kebutuhan pada masa sekarang ini tanpa mengorbankan kemampuan generasi penerus untuk memenuhi kebutuhan mereka sendiri. Sustainable development meliputi tiga aspek yaitu lingkungan, ekonomi, dan social sustainability (Chan dkk, 2017). Green building telah diterima dengan baik oleh pemerintah di seluruh dunia sebagai strategi 
untuk meningkatkan keberlanjutan industri konstruksi (Shen dkk, 2017). Green building merupakan penerapan peciptaaan struktur dengan menggunakan proses sebagai wujud tanggung jawab kepada lingkungan dan diharapkan akan menghemat sumber daya di bangunan selama siklus hidup gedung (US Environmental Protection Agency (USEPA), 2016). Terdapat beberapa aspek atau elemen yang akan mempengaruhi suatu bangunan dapat diberi label green building. Elemen tersebut antara lain pengolahan lahan yang efektif, penghematan energi dan penggunaan energi konservasi, penghematan konsumsi air, pemilihan material yang tepat, pengkondisian udara dan penciptaan kenyamana udara dalam ruang serta manajemen lingkungan bangunan (GBCI, 2020). Dari enam elemen tersebut yang sangat mempengaruhi adalah elemen konsumsi energi karena kaitannya tidak hanya pada kenyamanan penghuni di dalam ruang tetapi juga akan erat sekali kaitannya dengan aspek ekonomi. Upaya untuk dapat mengurahi besarnya konsumsi energi yang ada di dalam bangunan antara lain mengaplikasikan desain yang mampu menurunkan nilai energi seperti menurunkan persentase bukaan, pemilihan material transparan yang tepat dan menambahan aplikasi peneduh (Ayuningtyas, 2017). Green materials telah dianggap sebagai salah satu unsur penting dalam merancang proyek konstruksi berkelanjutan yang berwawaskan lingkungan, dimana penelitian telah menyoroti penggantian semen adalah metode populer untuk mengurangi gas rumah kaca (greenhouse gas) dan penggantian bahan perawatan pada beton (Sandayanake dkk, 2020). Penggunaan materil insulasi organik dan anorganik untuk bangunan, yang berupa kaca daur ulang wol domba merupakan piihan yang paling tepat diantara beberapa bahan yang lainnya (Streimikiene dkk, 2020). Hal-hal tersebut telah dipandang sebagai suatu alternatif untuk bangunan tradisional dan moderen, yang memiliki peran penting dalam mengurangi atau menghilangkan dampak negatif kegiatan konstruksi pada lingkungan dan perubahan iklim (Hwang dkk, 2016 ; World Green Building Council (WorldGBC), 2017).

\section{Metode}

Tinjauan terhadap literatur telah dipahami sebagai metode untuk memungkinkan para peneliti untuk memetakan wilayah intelektual yang telah ada (Weed, 2006). Penelitian ini menggunakan metode studi literatur, yang berjumlah 15 jurnal antara tahun 2019-2020, dimana referensinya diperoleh dari Scopus dan Web of Science.

\section{Hasil dan pembahasan}

\begin{tabular}{|c|c|c|c|}
\hline No & $\begin{array}{c}\text { Variabel Yang } \\
\text { Mempengaruhi atau } \\
\text { Dipengaruhi }\end{array}$ & Peneliti & Hasil Penelitian \\
\hline 1 & $\begin{array}{l}\text { Federal policy, local } \\
\text { policy (LEED rating } \\
\text { systems) }\end{array}$ & Adekanye dkk (2020) & $\begin{array}{l}\text { Federal policy dan peningkatan } \\
\text { pada sistem rating LEED } \\
\text { berkaitan dengan peningkatan } \\
\text { sertifikasi LEED }\end{array}$ \\
\hline 2 & $\begin{array}{l}\text { Environmental, } \\
\text { social, dan economic } \\
\text { sustainability }\end{array}$ & Boahua dkk (2020) & $\begin{array}{l}\text { Environmental, social, dan } \\
\text { economic sustainability } \\
\text { mengalami perubahan signifikan } \\
\text { selama tiga dekade terakhir }\end{array}$ \\
\hline 3 & $\begin{array}{l}\text { Construction waste } \\
\text { minimization }\end{array}$ & Chi dkk (2020) & $\begin{array}{l}\text { Tidak terdapat perbedaan } \\
\text { Construction waste minimization } \\
\text { performance pada green } \\
\text { building di US dan China }\end{array}$ \\
\hline 4 & Rating tools & Gui dan Gou (2020) & $\begin{array}{l}\text { NABERS merupakan rating } \\
\text { tools yang dapat membedakan } \\
\text { performance bangunan lebih } \\
\text { efektif dengan menggunakan } \\
\text { certification level yang berbeda }\end{array}$ \\
\hline 5 & $\begin{array}{l}\text { Government's } \\
\text { strategy dan } \\
\text { Developer's strategy }\end{array}$ & Fan dan Hui (2020) & $\begin{array}{l}\text { Price premium dan level and } \\
\text { affordability of incentives } \\
\text { mempengaruhi green building } \\
\text { incentives }\end{array}$ \\
\hline 6 & Indoor environment & Du dkk (2020) & Indoor environment quality \\
\hline
\end{tabular}




\begin{tabular}{|c|c|c|c|}
\hline & quality & & $\begin{array}{lll}\text { berpengaruh terhadap } & \text { green } \\
\text { building }\end{array}$ \\
\hline 7 & Life cycle cost & Gopanagoni dan Velpula (2020) & $\begin{array}{l}\text { Life cycle cost berpengaruh } \\
\text { terhadap green building }\end{array}$ \\
\hline 8 & $\begin{array}{l}\text { Risk } \\
\text { interdependencies }\end{array}$ & Guan dkk (2020) & $\begin{array}{ll}\text { Risk } & \text { interdependencies } \\
\text { berpengaruh } & \text { terhadap green } \\
\text { building } & \end{array}$ \\
\hline 9 & $\begin{array}{l}\text { Neighborhood-level } \\
\text { vulnerability to } \\
\text { climate change }\end{array}$ & $\begin{array}{l}\text { Houghton dan Castillo-Salgado } \\
\text { (2020) }\end{array}$ & $\begin{array}{l}\text { Tidak terdapat korelasi antara } \\
\text { clusters of protective green } \\
\text { building strategies dengan } \\
\text { clusters of vulnerable } \\
\text { populations }\end{array}$ \\
\hline 10 & $\begin{array}{lr}\text { Climate, } & \text { policy, } \\
\text { hydrology } & \text { dan } \\
\text { geography } & \end{array}$ & Jiang dkk (2020) & $\begin{array}{l}\text { Policy dan climate berpengaruh } \\
\text { terhadap green building rating } \\
\text { tools }\end{array}$ \\
\hline 11 & $\begin{array}{l}\text { Indoor } \\
\text { environmental } \\
\text { quality }\end{array}$ & Lee dkk (2020) & $\begin{array}{l}\text { Tidak ada perbedaan indoor } \\
\text { environmental quality pada } \\
\text { green building, dibandingkan } \\
\text { antara refurbished dan yang baru }\end{array}$ \\
\hline 12 & Environmental water & Madad dkk (2020) & $\begin{array}{ll}\text { Environmental } & \text { water } \\
\text { berpengaruh terhadap } \\
\text { building }\end{array}$ \\
\hline 13 & Initial design & Wu dkk (2020) & $\begin{array}{l}\text { Initial design berpengaruh } \\
\text { terhadap green building }\end{array}$ \\
\hline 14 & Rating tools & Zou (2019) & $\begin{array}{l}\text { LEED lebih banyak digunakan } \\
\text { daripada three stars, dimana } \\
\text { keduanya mempengaruhi green } \\
\text { building }\end{array}$ \\
\hline 15 & Rating tools & Atanda dan Olukoya (2019) & $\begin{array}{l}\text { Rating tools mempengaruhi } \\
\text { green building }\end{array}$ \\
\hline
\end{tabular}

Penelitian-penelitian tersebut menunjukkan beberapa variabel yang berkaitan dengan green building. Adekanye dkk (2020) menyampaikan perlunya peraturan untuk implementasi green building, yang dalam penelitiannya diukur dengan menggunakan LEED rating systems. Berkaitan dengan rating tools, Zou (2019) menunjukkan bahwa LEED lebih banyak digunakan daripada three stars, serta Atanda dan Olukoya (2019) menunjukkan LEED banyak digunakan untuk menilai standar green building di Nigeria. Du dkk (2020) menunjukkan bahwa indoor environment quality berpengaruh terhadap green building, yang didasarkan pada persepsi masyarakat yang menggunakannya. Penelitian Lee dkk (2020) menunjukkan tidak ada perbedaan indoor environment quality antara bangunan refurbished dengan yang baru. Hal ini menunjukkan bahwa berkaitan dengan isu lingkungan, maka penggunaan bangunan refurbished lebih disarankan karena tidak adanya perbedaan indoor environment quality dengan bangunan baru. Penggunaan kapabilitas green building juga belum maksimal, seperti yang ditunjukkan Madad dkk (2020), yang menyatakan bahwa kapabilitas green building baru digunakan sebanyak $11 \%$, yang berarti masih banyak potensi yang belum tergali dengan adanya green building. Penelitian Wu dkk (2020) dapat dilanjutkan dengan penelitian Gopanagoni dan Velpula (2020) untuk dapat mengetahui keberlanjutan dari green building.

Seperti tersebut diatas, elemen dalam penilaian green building antara lain pengolahan lahan yang efektif, penghematan energi dan penggunaan energi konservasi, penghematan konsumsi air, pemilihan material yang tepat, pengkondisian udara dan penciptaan kenyamanan udara dalam ruang serta manajemen lingkungan bangunan (GBCI, 2020). GBC Indonesia (Green Building Council Indonesia) merupakan lembaga nonprofit satu-satunya di Indonesia yang berhak memberi sertifikasi sebuah bangunan/kawasan di Indosia layak dikatakan sebagai green building atau tidak. GBC Indonesia memiliki rating tool yang harus dipenuhi oleh para perancang/arsitek/konsultan/kontraktor yang akan menciptakan bangunan dengan konsep green building. Untuk perangkat tolok ukur bangunan hijau di Indonesia, GBC Indonesia mengeluarkan sistem rating yang dinamakan GREENSHIP. GREENSHIP dipersiapkan dan disusun oleh Green Building Council Indonesia dengan mempertimbangkan kondisi, karakter 
alam serta peraturan dan standar yang berlaku di Indonesia. GREENSHIP disusun dengan melibatkan para pelaku sektor bangunan yang ahli di bidangnya seperti arsitek, industri bangunan, teknisi mekanikal elektrikal, desainer interior, arsitek lansekap, dan lainnya (sumber : https://www.gbcindonesia.org/greenship, diakses pada 10 Juni 2020 pukul 02.00).

Wujud perhatian masyarakat di Indonesia terkait green building saat ini mulai meningkat. Hal ini dikarenakan beberapa pemerintah daerah di Indonesia telah mengeluarkan peraturan yang mewajibkan para pelaku konstruksi untuk menerapkan konsep green building tersebut. Beberapa daerah yang telah menerapkan yaitu DKI Jakarta, Bandung, Makasar dan Semarang. Kepedulian pemerintah terkait lingkungan yang semakin tinggi ini harapannya semakin mampu mengedukasi masyarakat luas terkait pentingnya menjaga kondisi lingkungan yang mulai memburuk saat ini. Keempat kota yang telah menerapkan peraturan pemerintah etempat terkait green building ini tidak akan mengeluarkan izin membangun apabila tidak menerapkan aspekaspek green building.

Meskipun tingkat kepedulian masyarakat tentang lingkungan dan upaya menciptakan green building mulai meningkat, tetap ada kontra yang selalu muncul di lingkungan masyarakat. Hal ini dikarenakan ketika para pelaku konstruksi maupun masyarakat yang ingin membuat bangunan dengan konsep green building akan memakan biaya yang cukup besar di awal pelaksanaan proyek hingga bangunan ini siap huni. Hal ini lah yang sering membuat masyarakat enggan mengaplikasikan konsep tersebut. Padahal apabila ditelaah lebih lanjut kedepannya saat bangunan sudah mulai dioperasionalkan, justru bangunan ini akan menghemat biaya operasional yang cukup signifikan dibandingkan pada bangunan yang tidak menerapkan konsep green building . Studi kasus yang dapat diambil antara lain pada bangunan Kementrian Pekerjaan Umum dan Perumahan Rakyat serta pada bangunan Kementrian Kelautan dan Perikanan. Di Bangunan Kementrian Pekerjaan Umum dan Perumahan Rakyat yang memperoleh sertifikat Platinum dari GBCI berhasil menghemat konsumsi energi listrik sebesar $65 \%$, sedangkan pada bangunan Kementrian Kelautan dan Perikanan yang bersertifikat Gold dari GBCI berhasil meraih juara I pada tahun 2018 di Subroto Awards sebagai Energy Efficient New Large Building dan Juara 1 di ajang ASEAN Energy Award Tahun 2019 kategori Energy Efficient Building, sub kategori New and Existing Building, bersanding dengan Gedung South Beach dari Singapore dan Central Plaza Rayong dari Thailand. Nilai penghematan yang diperoleh gedung Kantor Kementrian Kelautan dan Perikana ini antara lain mampu menghemat biaya listrik Rp. 2,466,805,250 / tahun, menghemat biaya konsumsi air PDAM sebesar Rp 269,167,360/tahun (Sumber : DPE Lab, 2019).

\section{Simpulan}

Berdasarkan variabel-variabel yang ditunjukkan pada penelitian-penelitian tersebut, penerapan green building di Indonesia perlu dilaksanakan. Hal ini dapat dimulai dengan membuat peraturan yang mendorong aplikasi green building, terutama untuk perkantoran, sekolah, universitas, yang dapat dimulai dari kantor-kantor pemerintah, seperti halnya yang telah dilakukan dengan adanya peraturan tentang kendaraan listrik atau bebas emisi. Penerapannya dapat diawali dengan pemikiran perencanaan desain bangunan sejak awal yang akan menerapkan konsep green building dan konsistensi pemilik gedung hingga masa operasional bangunan. Setelah itu dapat menerapkan aspek-aspek pendukung seperti instalasi solar cell untuk mereduksi penggunaan energi listrik, menangkap air hujan untuk dimanfaatkan ulang sebagi sumber air bersih yang tidak ntuk konsumsi manusia (untuk siram taman dan toilet).

Saran untuk penelitian selanjutnya adalah memasukkan variabel maintenance pada masa operasional bangunan, dan mensimulasikan jika bangunan tersebut over or low-performance.

\section{Referensi}

Adekanye, Oluwatobi G., Davis, Alex., dan Azevedo, Ines L. 2020. Federal policy, local policy, and green building certifications in the U.S. Energy \& Buildings.

https://doi.org/10.1016/j.enbuild.2019.109700 
Atanda, Jubril Olakitan., dan Olukoya, Obafemi A. P. 2019. Green building standards: Opportunities for Nigeria. Journal of Cleaner Production. https://doi.org/10.1016/j.jclepro.2019.04.189

Boahua, Wen., Musa, Nurmaya., Chuen, Onn Chiu., Ramesh, S., Lihua, Liang., dan Wei, Wang. 2020. Evolution of sustainability in global green building rating tools. Journal of Cleaner Production. https://doi.org/10.1016/j.jclepro.2020.120912

Chan, Albert Ping Chuen., Darko, Amos., Olanipekun, Ayokunle Olubunmi., dan Ameyaw, Ernest Effah. 2017. Critical Barriers to Green Building Technologies Adoption in Developing Countries: The Case of Ghana. Journal of Cleaner Production. https://doi.org/10.1016/j.jclepro.2017.10.235

Chen, Po-Ju., dan Wang, Fu-Cheng. 2017. Design optimization for the hybrid power system of a green building. International Journal of Hydrogen Energy. https://doi.org/10.1016/j.ijhydene.2017.12.020

Chi, Bin., Lu, Weisheng., Ye, Meng., Bao, Zhikang., dan Zhang., Xiaoling. 2020. Construction waste minimization in green building: A comparative analysis of LEED-NC 2009 certified projects in the US and China. Journal of Cleaner Production.

https://doi.org/10.1016/j.jclepro.2020.120749

Du, Xiaohui., Zhang, Yongchao., dan Lv, Zhengquan. 2020. Investigations and analysis of indoor environment quality of green and conventional shopping mall buildings based on customer's perception. Building and Environment. https://doi.org/10.1016/j.buildenv.2020.106851

Fan, Ke., dan Hui, Eddie, C. M. 2020. Evolutionary game theory analysis for understanding the decision-making mechanisms of governments and developers on green building incentives. Building and Environment. https://doi.org/10.1016/j.buildenv.2020.106972

Gonapagoni, Varshini., dan Velpula, Sree Lakshmi. 2020. An analytical approach on life cycle cost analysis of a green building. Materials Today: Proceedings. https://doi.org/10.1016/j.matpr.2020.04.226

Guan, Li., Abbasi, Alireza., dan Ryan, Michael J. 2020. Analyzing green building project risk interdependencies using Interpretive Strustural Modelling. Journal of Cleaner Production. https://doi.org/10.1016/j.jclepro.2020.120372

Gui, Xuechen, dan Gou, Zhonghua. 2020. Association between green building certification 1 evel and post-occupancy performance: Database analysis of the National Australian Built Environment Rating System. Building and Environment. https://doi.org/10.1016/j.buildenv.2020.106971

Hartman, Cathy L., dan Stafford, Edwin R. 1997. Green Alliances: Building New Business with Environmental Groups. Long Range Planning, Vol 30, No 2, pp 184-196

Houghton, Adele., Castillo-Salgado, Carlos. 2020. Analysis of correlations between neighborhoddlevel vulnerability to climate change and protective green building design strategies: A spatial and ecological analysis. Building and Environment. https://doi.org/10.1016/j.buildenv.2019.106523

Hwang, B. G., Zhu, L., dan Ming, J. T. T. 2016. Factors affecting productivity in green building construction projects: The case of Singapore. Journal of Management in Engineering. https://doi.org/10.1061/(ASCE)ME.1943-5479.0000499 
Jiang, Boya., Song, Yifan., Li, Hong Xian., Lau, Stephen Siu-Yu., dan Lei, Qinghua. 2020. Incorporating biophilic criteria into green building rating tools: Case study of Green Mark and LEED. Environmental Impact Assessment Review. https://doi.org/10.1016/j.eiar.2020.106380

Lee, Jan-Young., Wargocki, Pawel., Chan, Yiong-Huak., Chen, Liu., dan Tham, Kwok-Wai. 2020. How does indoor environmental quality in green refurbished office buildings compare with the one in new certified buildings? Building and Environment. https://doi.org/10.1016/j.buildenv.2020.106677

Madad, A., Gharagozlou, A., Majedi, H., dan Monavar, S. M. 2020. Considering water ecological aspects in developing a quantitative climatic model of urban green building using monetary valuations. Ecological Economics. https://doi.org/10.1016/j.ecolecon.2019.106562

Sandayanake, Malindu., Gunasekara, Chamila., Law, David., Zhang, Guomin., Setunge, Sujeeva., dan Wanijuru, Dennis. 2020. Sustainable criterion selection framework for green building materials - An optimization based study of fly-ash Geopolymer concrete. Sustainable Materials and Technologies. https://doi.org/10.1016/j.susmat.2020.e00178

Streimikiene, Dalia., Skulskis, Virgilijus., Balezentis, Tomas., dan Agnusdei, Giulio Paolo. 2020. Uncertain multi-criteria sustainability assessment of green building insulation materials. Energy \& Buildings. https://doi.org/10.1016/j.enbuild.2020.110021

UNEP. 2011. Sustainable buildings and climate initiatives. http://www.unep.org/sbci/pdfs/ sbci_2pager_eversion_Feb2011.pdf

USEPA. 2016. Definition of green building. https://archive.epa.gov/greenbuilding/web/html/about.html

Weed, Mike. 2006. Sports Tourism Research 2000-2004: A Systematic Review of Knowledge and a Meta-Evaluation of Methods. Journal of Sport \& Tourism. https://doi.org/10.1080/14775080600985150

WorldGBC. 2017. What is Green Building? http://www.worldgbc.org/what-green-building

Wu, Xiaoying., Lin, Borong., Papachristos, George., Liu, Pei., dan Zimmerman, Nici. 2020. A holistic approach to evaluate building performance gap of green office buildings: A case study in China. Building and Environment. https://doi.org/10.1016/j.buildenv.2020.106819

Zou, Yonghua. 2019. Certifying Green Buildings in China: LEED vs 3-Star. Journal of Cleaner Production. https://doi.org/10.1016/j.jclepro.2018.10.204

Ayuningtyas, Nurina Vidya. 2017. Pengaruh Nilai Operative Temperature terhadap Tingkat KOnsumsi Energi Bangunan Kantor. Tesis Departemen Arsitektur UGM. Yogyakarta

https://www.gbcindonesia.org/greenship (Diakses 10 Juni 2020 Pukul 02.00) 